\title{
Discours
}

Revue de linguistique, psycholinguistique et

informatique. A journal of linguistics, psycholinguistics and computational linguistics

$21 \mid 2017$

Varia

\section{The Role of the English It-Cleft and the French C'est-Cleft in Research Discourse}

\section{Charlotte Bourgoin}

\section{(2) OpenEdition}

Journals

Electronic version

URL: http://journals.openedition.org/discours/9366

DOI: $10.4000 /$ discours.9366

ISSN: 1963-1723

Publisher:

Laboratoire LATTICE, Presses universitaires de Caen

\section{Electronic reference}

Charlotte Bourgoin, «The Role of the English It-Cleft and the French C'est-Cleft in Research

Discourse », Discours [Online], 21 | 2017, Online since 22 December 2017, connection on 01 May 2019. URL : http://journals.openedition.org/discours/9366 ; DOI : 10.4000/discours.9366 

Revue de linguistique, psycholinguistique et informatique

\section{The Role of the English It-Cleft and the French C'est-Cleft in Research Discourse}

\section{Charlotte Bourgoin}

Centre de linguistique inter-langues, de lexicologie, de linguistique anglaise et de corpus -

Atelier de recherche sur la parole (CLILLAC-ARP) - EA 3967

Université Paris Diderot - Paris 7

Charlotte Bourgoin, «The Role of the English It-Cleft and the French C'est-Cleft in Research Discourse», Discours [En ligne], 21 | 2017, mis en ligne le 22 décembre 2017.

URL: http://journals.openedition.org/discours/9366

Titre du numéro: Varia

Coordination: Nicolas Hernandez \& Christian Raymond 



\title{
The Role of the English It-Cleft and the French C'est-Cleft in Research Discourse
}

\author{
Charlotte Bourgoin \\ Centre de linguistique inter-langues, de lexicologie, de linguistique anglaise et de corpus - \\ Atelier de recherche sur la parole (CLILLAC-ARP) - EA 3967 \\ Université Paris Diderot - Paris 7
}

Despite extensive work on cleft constructions, little attention has been given to their functions in specialised discourse. Using a collection of 40 research articles from the KIAP corpus, this study aims at establishing the role of clefts in English and French research discourse. The quantitative analysis reveals a higher frequency of clefts in French. The study also shows that clefts can help authors increase semantic continuity, reinforce the structure of articles and increase discursive coherence. Clefts thus facilitate the readership's understanding of the argumentation. From a contrastive viewpoint, the study of the different authorial roles - writer, researcher, arguer, quoter, presenter - reveals that English-speaking researchers tend to be more reader-oriented than French-speaking ones. This study thus gives new insight into the way argumentation is built in research articles and paves the way for further research on the differences between French and English research discourse.

Keywords: clefts, information structure, research discourse, contrastive study French-English

Bien que beaucoup de travaux sur les constructions clivées aient été réalisés, il n'y a eu que peu d'attention portée à leur aspect fonctionnel dans le discours spécialisé. En travaillant sur un corpus de 40 articles de recherche issus du corpus KIAP, cette étude a pour but d'établir le rôle des clivées dans le discours scientifique en français et en anglais. L'analyse quantitative révèle un nombre plus élevé de clivées en français. La recherche montre également qu'elles peuvent aider les auteurs à créer une continuité sémantique, consolider la structure d'un article et augmenter la cohérence discursive. Les constructions clivées facilitent donc la compréhension de l'argumentaire par le lecteur. D'un point de vue contrastif, l'étude des différents rôles attribués à l'auteur - rédacteur, chercheur, argumentateur, référenceur, présentateur - révèle que les chercheurs anglophones ont tendance à être plus subjectifs et portés vers le lecteur que les francophones. Cet article donne donc une nouvelle vision de la manière dont l'argumentation est construite dans les articles de recherche et offre la possibilité de conduire des études plus approfondies sur les différences entre le discours scientifique en français et en anglais.

Mots clés: clivées, structure de l'information, discours scientifique, étude contrastive français-anglais

\section{Introduction}

Despite there being numerous studies conducted on both clefts and research discourse, very little has been done to analyse the interaction between the two. The present study examines the role that cleft constructions, which are common to English and French, play in specialised discourse regarding syntax, semantics, and pragmatics. More specifically, I focus on the English it-cleft and its French equivalent, the c'est-cleft, which are illustrated in the following examples: 
[1] In the case of English middles, it is the agent argument, not the patient, that is unexpressed although it is often obligatory in other contexts.

(englin36)

[2] On estime en général que c'est finalement au niveau empirique que la question doit être tranchée.

(frecon04)

The data under study are taken from the KIAP corpus ("Kulturell Identitet i Akademisk Prosa" / "Cultural Identity in Scientific Discourse"), a collection of research articles in English, French, and Norwegian, in three disciplines, economics, linguistics, and medicine.

The first goal of this research is to establish the defining features of cleft constructions when used in research articles as opposed to clefts in non-specialised discourse. To do so, syntactic, semantic, and pragmatic analyses have been combined. The second goal is to compare the use of it-clefts and c'est-clefts to characterise English and French research discourse. It has been suggested by Carter-Thomas (2009) and Dufter (2009) that French relies more frequently on clefts to circumvent its strict SVO (subject-verb-object) structure. By modifying the information structure of clauses, clefts shift the primary focus to indicate newsworthiness. English, unlike French, does not necessarily require the use of clefts as either prosody or the preceding context, or both, are usually sufficient to mark focus on elements in preverbal position in English (Carter-Thomas, 2002; Lambrecht, 1994). Therefore, I will discuss the frequency of use of clefts in both languages and attempt to justify their use in English articles in comparison to French articles.

By investigating the syntactic features of clefts, this study shows that clefts in specialised discourse do not differ from clefts in non-specialised discourse (see Section 1). The semantic analysis highlights the role played by clefts in reinforcing the semantic continuity of research articles. The analysis of their functions reveals that clefts participate in the establishment of a framework or structure for articles and also help researchers guide their readership by inducing a particular meaning. The characterisation of the discursive position of clefts, the authorial role assigned and the nature of the information also point to the discursive coherence and explicit structure that the use of such "focus-marking devices" (Lambrecht, 2001) increases. Overall, the results will allow me to shed light on the differences between English and French research discourse. While the former appears to be more "reader-oriented",

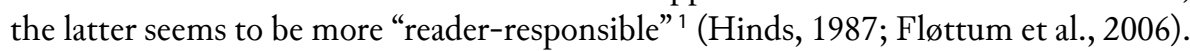

1. Hinds (1987) distinguishes between two types of languages: "writer-responsible" and "reader-responsible" languages. In writer-responsible - also called "reader-oriented” by Fløttum et al. (2006) - languages, it is the speaker who is responsible for making his or her utterance clear and well-organised. This tradition is rooted in Anglo-American academic writing. In reader-responsible languages, on the other hand, it is the addressee who is responsible for making sense of the utterance. Fløttum et al.'s (2006) study shows that French tends to be more reader-responsible than reader-oriented. 
In this article, I will first present the main properties of research discourse as defined by linguists in recent studies. I will then explain how my corpus was built and annotated to focus on the semantic and pragmatic aspects of clefts. I will finally discuss the results of both the quantitative and qualitative analyses performed.

\section{Features of research discourse}

Linguists have attempted to define the main characteristics of specialised discourse and account for the possible differences between languages. This section will present an overview of the features of research articles in French and English.

\subsection{Argumentative style}

The primary function of research articles is for researchers to present and defend their findings on a given topic while drawing comparisons with pre-existing studies. This motivation contributes to the highly argumentative nature of such articles. Linguists have established a list of grammatical tools typical of academic writing. Among these grammatical devices, Pic and Furmaniak (2012) highlight the use of modals as hedges to qualify findings and the combination of specific discursive modes such as the metadiscursive, argumentative and informative modes. Clarity and continuity may be achieved through the use of anaphora and punctuation (Poncharal, 2010) or clause-initial elements that allow authors to organise their articles by making their structure more explicit (Celle \& Lansari, 2014). In the same way, metadiscourse and metatext are typical of research discourse as they serve to set a frame and negotiate academic knowledge (Hyland, 1998; Fløttum et al., 2006) by anticipating the reader's objections. Interrogatives may also be used to pre-empt possible questions of the readership (Celle, 2013). Both metadiscourse and interrogatives establish an interaction between author and reader. This interactive process is also revealed through directives, whose goal is to direct the reader to other resources or sections of the article (Hyland, 2002b). It is, therefore, a combination of devices rather than separate elements that allows the author to create a persuasive environment in a research article.

When talking about author/reader interaction, it is essential to specify that this interactive process differs significantly between French and English. Recent publications show that while English research discourse tends to be more readeroriented, French research discourse is more reader-responsible. For instance, the use of metatext is more frequent in English than in French, which stems from a difference in cultural identity as well as academic training (Fløttum et al., 2006). Another case in point is clause-initial elements: in English, they have metaenunciative properties and guide the reader throughout the article whereas they are more closely related to the content of the articles in French (Celle \& Lansari, 2014; Carter-Thomas, 2014). The two languages also differ regarding repetitions and connectors, which are more frequent in French (Poncharal, 2010). All these 
studies thus point to a difference in "argumentative style" (Carter-Thomas, 2014) in French and English research discourse. I will, therefore, examine whether this difference applies to the use of clefts. I will also attempt to see whether clefts play a role as regards the opposition between reader-oriented vs. speaker-oriented languages.

\subsection{Authorial identity}

Although research articles are highly argumentative, linguists have found that they tend to remain neutral regarding the author's implication. Fløttum et al. (2006) point out that:

Every text has a responsible author, or a responsible group of authors. This also holds for the research article, although this and related genres have often been considered as relatively objective and impersonal, exhibiting few traces of the researcher.

(Fløttum et al., 2006: 67)

However, they also argue that research articles cannot be completely free of subjective traces. According to them, all academic writers have what they call a "cultural identity" that is shaped by a number of factors. These factors include national identity, academic identity, disciplinary identity, and discourse community. These features can be fixed like national identity or evolving like academic identity, and they account for the traditions followed by researchers. Hyland (2002a) also addresses the question of cultural identity in his study on the pragmatic aspect of authorial identity. He argues that academic writing is constrained by already existing conventions both at the social and educational levels. However, academic texts still require positioning on the part of the author. For this reason, Hyland (2002a: 1092) assimilates academic writing to an "act of identity" that "not only conveys disciplinary 'content' but also carries a representation of the writer". Cultural identity thus accounts for the stylistic differences among disciplines and researchers and it also, to a certain extent, explains the nature and frequency of the authorial traces that can be found in research articles. The results of Fløttum et al.'s (2006) study show that the manifestations of the author's voice can take the form of personal pronouns, imperatives or negations. The study also reveals the existence of four different authorial roles: writer, researcher, arguer, and evaluator. The central grammatical element that gives evidence for these four roles is verbs. The writer favours discourse verbs such as describe or return, the researcher uses research verbs such as calculate, conduct and analyse, the arguer uses position verbs such as claim, argue or believe and finally, the evaluator tends to favour evaluation or emotion verbs and expressions such as find or be sceptical. Consequently, authorial traces can be studied in terms of grammatical and lexical items. This is in accordance with the studies on other linguistic resources such as metadiscourse, hedges and discursive modes previously mentioned. Besides, Hyland (2002a) claims that possessive determiners are also a way for authors to display their voices. Authorial identity, therefore, is expressed through a combination of elements. 
Research articles not only reflect one author's perspective but also offer the possibility for other researchers to be present. Fløttum et al. (2006) claim that citations give other researchers a voice of their own. The type of reference used determines the degree of importance assigned to this voice. Fully integral references using reported speech are a good example of polyphony; the researcher is reporting someone else's claim without taking responsibility for it. CarterThomas and Rowley-Jolivet (2013) also underline the role of expressions such as according to in presenting another voice in the discourse. Fløttum et al. claim that the presence of others can also be achieved through negation and more particularly refutative negation. By refuting other researchers' ideas, the author positions him- or herself in a scientific community. In this case, it is a rather high degree of polyphony as both the author and the other researchers express their ideas. To sum up, research discourse does not only allow researchers to present their ideas but can also give a voice to other researchers through the use of various linguistic tools.

\section{Data}

\subsection{Corpus}

Granger et al. (2003: 18) state that corpus linguistics is "increasingly focusing on cross-linguistic issues". The shift to comparative approaches is especially true for languages like English or French, for which large corpora exist. Dufter (2009) and Carter-Thomas (2009) both rely on corpus-based analyses of clefts to investigate their function in political speech for the former and journalistic discourse for the latter. The present study is also in line with their studies by addressing the following question: do clefts play a role in the argumentative aspect of research discourse and is this role the same in English and French research discourse? This question implies other issues such as whether the frequency of use of cleft structures is higher in French or English. The hypothesis put forward in this article and based on the previous research mentioned above is that clefts are more frequent in French than in English. Several steps using corpus methods were necessary to test this hypothesis regarding research articles. For this research project, the analysis was limited to 239 occurrences gathered from 40 articles $^{2}(10$ French economics articles, 10 French linguistics articles, 10 English economics articles and 10 English linguistics articles) of the KIAP corpus. The final corpus represents 2,650,000 words. The size of the sub-corpora is shown in Table 1.

2. In order to ensure the scientific standards of the articles, Fløttum et al. (2006) who designed the KIAP corpus opted for peer-reviewed journals and avoided articles that only reviewed the current state of research. As for the native language of the writer, they explain: "As far as possible, texts have been chosen where the author (or at least one of the authors) appears to be a native speaker of the language in which the article is written (on the basis of his or her name and other information available)" (Fløttum et al., 2006: 9). 


\begin{tabular}{|l|l|l|l|}
\hline \multicolumn{2}{|c|}{ French sub-corpus } & \multicolumn{2}{c|}{ English sub-corpus } \\
\hline \multicolumn{2}{|c|}{$1,090,000$} & \multicolumn{2}{c|}{$1,560,000$} \\
\hline $\begin{array}{l}\text { Economic } \\
\text { sub-corpus }\end{array}$ & $\begin{array}{l}\text { Linguistic } \\
\text { sub-corpus }\end{array}$ & $\begin{array}{l}\text { Economic } \\
\text { sub-corpus }\end{array}$ & $\begin{array}{l}\text { Linguistic } \\
\text { sub-corpus }\end{array}$ \\
\hline 581,000 & 509,000 & 604,000 & 956,000 \\
\hline
\end{tabular}

Table 1 - Size of the sub-corpora (in number of words)

The first and most crucial step was the identification of cleft structures in the corpus. The aim was to find enough occurrences to work on and classify in order to use them as relevant examples for qualitative analysis. However, identifying syntactic structures such as clefts is a challenging process as it proves difficult to complete automatically with pre-existing software if the data have not first been annotated. Following the methodology used by Collins (1991) and using the search toolbar, I extracted structures by searching for elements proper to clefts such as the pronoun it followed by the third person singular form of the copula $b e$. It was then necessary to sort them manually to rule out the instances of extraposition, which are also introduced by the sequence it is and in which heavy constituents are placed at the end of the sentence. It is exemplified in [3a]. I also found restrictive relative clauses as in [3b], which are similar to clefts in terms of syntactic structure.

[3a] It may also be worth noting, that if one were to consider a production function augmented to include capital stock, costs would be a function of the labor-capital ratio.

(engecon21)

[3b] The social psychologist Michael Bond (personal communication) maintains that "face is too vague and metaphorical for social scientific use", and yet he also acknowledges that it is a very useful concept that needs to be elaborated. (engling23)

As far as the French sub-corpus is concerned, the identification of cleft constructions was carried out following the same methodology. However, because the initial element c'est introducing French clefts is only partly fossilised and agrees with the cleft element, there were two different forms to locate namely (i) c'est and (ii) ce sont as well as the negative forms (iii) ce n'est and (iv) ce ne sont. Again, this method of identification implied ruling out the occurrences that were not relevant to the study such as the recurrent expression c'est-à-dire. Once the process of identification was completed, all clefts were classified according to discipline and language.

\subsection{Annotating the corpus}

In order to identify the discourse function of clefts, both English and French occurrences were classified and annotated according to the five criteria listed opposite. 


\section{- Syntactic category of the clefted element}

The first criterion used to classify occurrences was the syntactic category of the clefted element. The focus induced by cleft constructions can be put on noun phrases (NPs), prepositional phrases (PPs), adverbial phrases, pronouns, subordinate clauses, or infinitive clauses. The aim is to see whether one category is dominant and if so whether the results follow Prince's (1978) claim that it-clefts mainly accept NPs. To a greater extent, the nature of the highlighted element may reveal the role of the information put into focus by the cleft as well as the role of the cleft, since depending on the category of the clefted element, the functional motivation is not the same.

\section{- Grammatical function of the clefted element}

The second criterion used was the grammatical function of the highlighted element. It can be the subject, the object or an adjunct. Determining the function goes hand in hand with establishing the syntactic category of the element and also allows us to see the purpose the cleft has in a broader context. Again, depending on the grammatical relation assigned to the clefted element, clefts will not have the same function in discourse.

- The author's role

Occurrences were also divided according to the role that could be assigned to the author. This criterion was based on Fløttum et al.'s (2006) study on academic discourse. As mentioned above, they argue that authors can take on different roles throughout their research articles such as the role of writer, researcher, arguer and evaluator. In their study, these roles are revealed through verbs. Because the present project deals with a different object, it appeared necessary to adjust this list. The role of evaluator was dropped, and two new categories were created: author as presenter and author as quoter. Clefts under the label "presenter" include facts with a very limited subjectivity and clefts under the label "quoter" include clefts introducing previous research and ideas.

\section{- Information structure}

Clefts were also classified according to the type of information contained in the clefted elements. The theoretical approach I adopt in this paper departs from the Praguian tradition that conflates thematic and information structure into one complex phenomenon. Instead, I follow Halliday's (1967) and Carter-Thomas's (2002) distinction between the two systems of theme/rheme and given/new. Since various definitions for the term "given" can be found in the literature on information structure (see Declerck, 1994), I chose to oppose "shared" and "non-shared" to circumvent this polysemy. Occurrences with clefted elements containing old information retrievable from the immediate context were labelled "shared" 
while occurrences with clefted elements containing new information were labelled "non-shared". The aim was to analyse the interaction between clefts and argumentation.

- Discursive position in the article

The last criterion for the classification of occurrences was the discursive position of clefts in the article. Since the majority of the articles of the corpus did not follow the IMRAD (Introduction, Methodology, Results, and Discussion) structure, the articles were broken into five parts: abstract, introduction, body, conclusion and notes. The position was the central factor in determining whether clefts were used to present a new argument, stress its importance by repeating it or conclude the argumentation.

\section{Analysis}

\subsection{Frequency of use}

Table 2 below presents the normalised frequency of use of clefts.

\begin{tabular}{|l|l|l|l|}
\hline \multicolumn{2}{|c|}{ French sub-corpus } & \multicolumn{2}{c|}{ English sub-corpus } \\
\hline \multicolumn{2}{|c|}{133.03} & \multicolumn{2}{c|}{60.26} \\
\hline $\begin{array}{l}\text { Economic } \\
\text { sub-corpus }\end{array}$ & $\begin{array}{l}\text { Linguistic } \\
\text { sub-corpus }\end{array}$ & $\begin{array}{l}\text { Economic } \\
\text { sub-corpus }\end{array}$ & $\begin{array}{l}\text { Linguistic } \\
\text { sub-corpus }\end{array}$ \\
\hline 68.85 & 206.29 & 52.98 & 64.85 \\
\hline
\end{tabular}

Table 2 - Normalised frequencies of use of clefts (per million words)

Cleft constructions are more numerous in the French sub-corpus than in the English sub-corpus and more frequent in the linguistic sub-corpora than economic sub-corpora. The log-likelibood (LL) test score for the comparison of the frequency of use between the two languages was 36.89 meaning that the level of significance of this is higher than $99.99 \%$. The results are in line with those of Carter-Thomas's (2009) study on journalistic discourse and Dufter's (2009) on political speech, which also showed a lower frequency of use of clefts in the English part of their corpora. This quantitative difference in the use of cleft constructions can be explained by the disparate treatment of information structure in French and English. Although French and English both have a strict SVO word order, English allows more readily a newsworthy reading of grammatical subjects in theme position through context alone (Carter-Thomas, 2002) or with sentence accents (Lambrecht, 2001; Katz, 2000). French, on the other hand, is much less flexible in the position of focus on preverbal constituents. Katz (2000) also argues that the English it-cleft is used for 
stylistic reasons rather than pragmatic ones. Since the difference in rigidity appears more clearly in translated examples, I will use an example from Carter-Thomas's (2002) comparative analysis of journalistic speech:

[4a] La mesure du phénomène reste délicate. Il n'existe aucune statistique officielle. Pour Emmanuelle Piet, ce sont la quasi-totalité des jeunes Turques, des Africaines du fleuve Sénégal et un grand nombre de jeunes Maghrébines qui sont menacées.

[4b] Pour Emmanuelle Piet, la quasi-totalité des jeunes Turques, des Africaines du fleuve Sénégal et un grand nombre de jeunes Maghrébines sont menacées.

[5] In Dr. Piet's view, almost all Turkish, Senegalese and a large number of North African girls are at risk.

As explained by Carter-Thomas (2002), the cleft in [4a] lays emphasis on and focalises the number, la quasi-totalité of girls who are at risk. This corresponds to the theme, i.e. what is talked about, of both the cleft and the canonical version in [4b]. However, it is the rheme sont menacées of the non-cleft structure that receives a newsworthy reading instead of the grammatical subject. The cleft thus allows the author to shift the newsworthiness onto the theme. In the English translation in [5], Carter-Thomas argues that it appears easier to attribute focal status and newsworthiness to the grammatical subject and theme almost all... and a large number of... The use of a cleft is, therefore, unnecessary.

As far as disciplines are concerned, the frequency of use also differs. Clefts seem to be more frequent in linguistics articles than in economics articles. This difference is revealed with the French economics and linguistics sub-corpora. The LL test score is 39.44 meaning that the level of significance of the difference is higher than 99.99\%. However, the English economics and linguistics sub-corpora do not confirm this difference. The LL test score for the comparison of the number of clefts in the English sub-corpus is only 0.88, which means that the level of significance is lower than $95 \%$ and that the difference is not statistically significant. The difference in the frequency of use of clefts in terms of the discipline factor thus requires further research.

\subsection{Syntactic properties}

\subsubsection{Syntactic category of the highlighted element}

The results of the analysis of the syntactic category of the highlighted elements are presented in Table 3.

The results reveal that the highlighted elements of clefts are very similar in both languages as well as in both disciplines. Neither the language nor the discipline plays a determining role syntactically. The dominant category is NPs as in Examples [6] to [9]. 


\begin{tabular}{|l|r|r|r|r|r|r|}
\hline & \multicolumn{3}{|c|}{ French } & \multicolumn{3}{c|}{ English } \\
\cline { 2 - 7 } & Economics & Linguistics & Subtotal & Economics & Linguistics & Subtotal \\
\hline Noun phrase & $77.5 \%$ & $69 \%$ & $71 \%$ & $84 \%$ & $66 \%$ & $72 \%$ \\
\hline $\begin{array}{l}\text { Prepositional } \\
\text { phrase }\end{array}$ & $17.5 \%$ & $24 \%$ & $23 \%$ & $16 \%$ & $23 \%$ & $21 \%$ \\
\hline Pronoun & 0 & $5 \%$ & $3 \%$ & 0 & $5 \%$ & $3 \%$ \\
\hline $\begin{array}{l}\text { Subordinate } \\
\text { clause }\end{array}$ & $2.5 \%$ & 0 & $1 \%$ & 0 & $5 \%$ & $3 \%$ \\
\hline $\begin{array}{l}\text { Adverbial } \\
\text { phrase }\end{array}$ & $2.5 \%$ & 0 & $1 \%$ & 0 & $1 \%$ & $1 \%$ \\
\hline $\begin{array}{l}\text { Infinitive } \\
\text { clause }\end{array}$ & 0 & $2 \%$ & $1 \%$ & 0 & 0 & 0 \\
\hline Total & $100 \%$ & $100 \%$ & $100 \%$ & $100 \%$ & $100 \%$ & $100 \%$ \\
\hline
\end{tabular}

Table 3 - Syntactic category of the clefted element

[6] Since it is [I] that defines the class of front vowels, we conclude that [I] must also be present in palatal and palatalized consonants.

(engling07)

[7] It is the members of that particular group who first trade using the shared information.

(engecon03)

[8] Plus fondamentalement, c'est la volatilité conditionnelle qui se révèle être de plus en plus souvent utilisée.

(frecon04)

[9] D'un côté, ce n'est pas non plus la vue d'une certaine lettre ou d'un certain groupe de lettres qui appelle cette sensation.

All four examples corroborate Prince's (1978) finding that it-clefts mainly have NPs as their clefted elements. As for French c'est-clefts, they are also mainly built on the prototypical syntactic model "c'est + NP + subordinate conjunction + subordinate clause" described by Collins (1991) and Declerck (1994). The similar syntactic distribution is also in line with Dufter's finding (2009) that the Romance and Germanic clefts in political speech select the same range of syntactic categories as their clefted constituent. Cleft constructions used in specialised discourse thus do not differ syntactically from regular clefts. 


\subsubsection{Grammatical function of the clefted element}

The results of the analysis of the grammatical function of the highlighted elements are presented in Table 4.

\begin{tabular}{|l|r|r|r|r|r|r|}
\hline & \multicolumn{3}{|c|}{ French } & \multicolumn{3}{c|}{ English } \\
\cline { 2 - 7 } & Economics & Linguistics & Subtotal & Economics & Linguistics & Subtotal \\
\hline Subject & $75 \%$ & $68 \%$ & $70 \%$ & $84 \%$ & $60 \%$ & $68 \%$ \\
\hline Adjunct & $20 \%$ & $16 \%$ & $17 \%$ & $13 \%$ & $31 \%$ & $25 \%$ \\
\hline Direct object & $2.5 \%$ & $7 \%$ & $6 \%$ & 0 & $3 \%$ & $2 \%$ \\
\hline $\begin{array}{l}\text { Indirect } \\
\text { object }\end{array}$ & $2.5 \%$ & $9 \%$ & $7 \%$ & 0 & $1 \%$ & $1 \%$ \\
\hline $\begin{array}{l}\text { Prepositional } \\
\text { object }\end{array}$ & 0 & 0 & 0 & $3 \%$ & $5 \%$ & $4 \%$ \\
\hline Total & $100 \%$ & $100 \%$ & $100 \%$ & $100 \%$ & $100 \%$ & $100 \%$ \\
\hline
\end{tabular}

Table 4 - Grammatical function of the clefted element

The results show that, besides prepositional objects, which do not occur in the French part of my corpus, the French and English sub-corpora both include the same grammatical functions for clefted elements. These results are in line with Dufter's (2009) showing that both Germanic and Romance clefts accept the same range of grammatical functions. The analysis also reveals that clefted elements mainly correspond to the subject of the embedded clause. It also coincides with Dufter's (2009) findings on political speech. In that sense, clefts in research articles differ neither from clefts in other types of specialised discourse nor from clefts in non-specialised speech. The higher proportion of grammatical subjects as focalised constituents also corroborates Carter-Thomas's (2002) argument that defining cleft constructions as thematising structures is insufficient. When the clefted element corresponds to the subject of the subordinate clause, there is no change in the thematic structure. The element in focus is the theme both in the canonical sentence and in the cleft. This line of reasoning is exemplified in [10] and [11] and their corresponding canonical structures:

[10a] It is the processing of these relations and their simultaneous working memory demands that appears to be the direct cause of distance effects, not conceptual structure or properties of the world per se.

(englin03)

[10b] The processing of these relations and their simultaneous working memory demands appears to be the direct cause of distance effects, not conceptual structure or properties of the world per se. 
[11a] C'est à la matière du mot (agencement purement mécanique mis en évidence par la grammaire comparée) que s'opposera sa forme.

(frling22)

[11b] Sa forme s'opposera à la matière du mot.

In [10a], the clefted constituent is the subject of the relative clause and corresponds to the theme of the sentence, i.e. what is being talked about. The focalised element can also be considered theme in the non-clefted structure in [10b]. The cleft thus does not change the thematic structure of the sentence. Unlike Example [10a], the cleft in [11a] selects the indirect object of the subordinate clause as its focalised constituent and thus as its theme. Example [11b] shows, however, that the clefted element would be the rheme in the corresponding non-cleft structure. In this case, the thematic structure is modified by the cleft, which combines theme and focus on the clefted element.

In brief, the syntactic analysis shows that clefts in research discourse do not differ from clefts in non-specialised discourse.

\subsection{Author roles}

Results regarding the role of the author in the corpus are presented in Table 5. As explained in more detail in Section 2, the categories correspond to the different roles that can be assigned to the author (writer, researcher, arguer, quoter or presenter). The "mixed" category includes ambiguous occurrences that appeared to contain multiple roles. The goal of this section is to determine whether clefts play a part in the establishment of authorial identity in research articles. We first discuss each authorial role.

\begin{tabular}{|l|r|r|r|r|r|r|}
\hline & \multicolumn{3}{|c|}{ French } & \multicolumn{3}{c|}{ English } \\
\cline { 2 - 7 } & Economics & Linguistics & Subtotal & Economics & Linguistics & Subtotal \\
\hline Presenter & $67 \%$ & $62 \%$ & $64 \%$ & $63 \%$ & $66 \%$ & $63 \%$ \\
\hline Researcher & $17 \%$ & $10 \%$ & $12 \%$ & $29 \%$ & $8 \%$ & $16 \%$ \\
\hline Quoter & $8 \%$ & $14 \%$ & $12 \%$ & $2 \%$ & $11 \%$ & $9 \%$ \\
\hline Arguer & $3 \%$ & $3 \%$ & $3 \%$ & 0 & $5 \%$ & $3 \%$ \\
\hline Writer & $0 \%$ & $5 \%$ & $3 \%$ & $6 \%$ & $8 \%$ & $7 \%$ \\
\hline Mixed & $5 \%$ & $6 \%$ & $6 \%$ & $2 \%$ & $2 \%$ & $2 \%$ \\
\hline Total & $100 \%$ & $100 \%$ & $100 \%$ & $100 \%$ & $100 \%$ & $100 \%$ \\
\hline
\end{tabular}

Table 5 - Author roles 


\subsubsection{Author as presenter}

Both present examples of facts connected to the matter of the articles. The cleft construction in [12] introduces a syntactic feature of the English language. In this case, it creates an explicit contrast between the agent argument and the patient through the negation not to underline the fact that it is only the former that remains unexpressed in English constructions. [12] exemplifies what Declerck (1988) describes as "contrastive clefts" and what Lahousse and Borremans (2014) call "narrow contrast". Concerning subjectivity, the assertive dimension is shown by the lack of modalisation. There are no modals or modal expressions that qualify the assertion. The statement is therefore objective, and the author has a neutral role that consists in relaying a piece of information. Example [13] follows a similar pattern. The element in focus au niveau des techniques économétriques utilisées corresponds to the point of departure of the most recent studies on the same object of study. The author is briefly reviewing the history of studies on volatility. Again, the utterance is neither grammatically nor lexically modalised, which makes the author appear more objective and neutral. In the same way as [12], the example taken from the French sub-corpus exemplifies the author's anticipatory strategy regarding the knowledge of the reader. It is therefore clear that facts lack traces of authorial identity and that the difference between English and French research discourse is not related to the author as presenter. 


\subsubsection{Author as researcher}

In Example [14], the author is explaining what the primary interest is regarding two examples presented in the study. Unlike in the category "presenter", the elements from the immediate context indicate the author's commitment. The use of the singular determiner my reveals that the author is engaging in a personal process whose goal is to present the whys and wherefores of the study in a clear way. The cleft, therefore, reinforces the discursive coherence of the article. In [15] the author is underlining both the notion and the framework he adopted. The preceding sentences give the nature of the notion, and the highlighted element takes it up. From a functional viewpoint, both clefts serve to guide the audience. The use of metalanguage related to research with nouns such as interest and notion helps the reader identify more quickly and more easily the hypotheses and ideas at stake in the articles. However, an interesting difference between the two languages is the use of the plural pronoun nous in [15]. The subject nous is followed by the corresponding reflexive pronoun nous, which indicates a mental process and thus refers to the author. The use of a plural pronoun in a single-authored article can be explained by the phenomenon of "moi baïssable" mentioned by Fløttum et al. (2006). According to them, French researchers tend to avoid first-person pronouns due to the social constraints imposed by their academic training, which insists on the importance of objectivity in articles. As for the English occurrence, the use of the first-person determiner $m y$ is justified by the personal nature of the motivation 
behind the writing of a research article. Consequently, it does not go against the idea of a closer reader-writer relationship in English research discourse.

\subsubsection{Author as quoter}

As already mentioned, one of the distinctive features of research discourse is the use of references. Bibliographical references, as categorised by Fløttum et al. (2006), whether direct or indirect, allow other researchers to be given a voice of their own. They are extensively used in research articles, whose main goal is to argue for and against the ideas of other researchers and participate in the interaction within the scientific community. Although in the case of our corpus, French seems to include more clefts highlighting the work of other researchers, the difference is not statistically significant. Regarding the discipline factor, however, the results show that clefts containing references are more frequent in linguistics than in economics. This finding corroborates the claim that economics focuses more on the description of a given system than on specific hypotheses (Fløttum et al., 2006) and therefore calls for fewer references. It is important to note that references presented in clefts are most of the time indirect as in [16] but can also be direct as in [17]:

[16] Wasow (1997) has shown that it is not only the heaviness of an NP that motivates the shift from [V NP PP] to [V PP NP] in English.

(engling03)

[17] "Depuis une vingtaine d'années, l'usage du terme 'pragmatique' s'est peu à peu affirmé dans la littérature linguistique, au point qu'il n'est pas inconvenant de parler de la pragmatique comme d'une branche des sciences du langage, voire de la linguistique." C'est en ces termes que Jacques Moeschler et Anne Reboul ouvrent leur Dictionnaire encyclopédique de pragmatique (1994: 17). (frling38)

'[...] It is in these terms that Jacques Moeschler and Anne Reboul open their Encyclopedic dictionary of pragmatics.'

Example [16] highlights the findings of Wasow regarding the shift in adjacency. The reference is introduced in the main clause containing the cleft. This corresponds to what Fløttum et al. (2006) call a partly integral reference, that is to say, the author of the article is reporting what Wasow has written through the use of indirect speech. Moreover, the author does not take responsibility for what has been said nor does he produce a judgement about it. The objectivity is similar to that of the author as presenter analysed previously. The findings of the other researcher are presented and given importance through the words of another author. This superposition of voices is in line with the ScaPoLine theory on polyphony ${ }^{3}$. The author of the article

3. The concept of polyphony was first introduced by Bakhtin (1984) who showed the presence of simultaneous points of view in Dostoïevski's poetry. Nølke et al.’s (2004) ScaPoLine theory ("théorie scandinave de la polyphonie linguistique") follows Bakhtin's findings and refutes the idea of an indivisible subject but 
is the source of the utterance while the other researcher mentioned only has a lesser role as he cannot intervene. He is assigned a role of researcher as proven by the research verb show. In Example [17], the author presents the viewpoint of two other researchers on the concept of pragmatics. The cleft construction follows a direct quote. We have here a fully integrated reference that also exemplifies the concept of polyphony. This time, however, the researchers who are mentioned are given a voice of their own. Their words are rendered with no alteration by the author. In this case, the quote is found at the very beginning of the abstract. The conclusion that emerges is that the goal of the reference is for the author to set a clear framework for his study and position himself in relation to his scientific community. In doing so, he is also introducing the subject of his article. Moreover, the cleft adds to the quote by providing the name of the authors as well as the title of their book in a more explicit way than the traditional citation format. This increases the visibility of the author's work. The two references thus have two different roles. In terms of their discursive motivation, [16] is close to the "presenter" category whereas [17] aims at setting the framework of the article.

\subsubsection{Author as arguer}

As already stated, research discourse is by definition highly argumentative. One motivation behind researchers' work is to present their hypotheses and defend them convincingly within their scientific community. In addition to the roles of researcher and writer, authors can take on the role of arguer. Occurrences that can be analysed as illustrating the role of arguer are equally abundant in the French sub-corpus as in the English one. As for disciplines, the proportion of the arguer role is the same among all the clefts in French economics and linguistics articles but is more frequent in English linguistics articles. The difference is nonetheless insignificant. Let us analyse two occurrences exemplifying the role of arguer:

[18] However, neither makes much of this; they tend rather to emphasise such features as those given in the previous section, while, in my view, it is the implicit (that is, not linguistically signalled) metarepresentational nature of material in the scope of the negation which is the single essential and unifying property of cases of metalinguistic negation.

(engling08)

[19] La technologie d'appariement nous semble bien adaptée aux marchés de logements. C'est, en effet, lorsque l'hétérogénéité entre deux groupes d'agents est importante qu'il est pertinent que la probabilité d'appariement dépende positivement du nombre des agents de l'autre groupe.

(frecon37)

departs from his work in that they consider the voices to be hierarchical rather than independent. Fløttum et al. (2006) highlight the relevance of ScaPoLine in the study of research discourse where several voices can be superposed but the author's point of view remains the primary one. 
'Matching technology seems to us best suited for the housing market. It is, indeed, when the heterogeneity between two groups of agents is substantial that it is relevant that the probability of matching positively depends on the number of agents in the other group.'

In [18], the author is sharing her point of view on metalinguistic negation. The prepositional phrase in my view and more particularly the possessive determiner indicate her commitment. Similarly to the role of researcher, the role of arguer is therefore distinguishable from that of presenter or quoter by the subjectivity of the clause. Moreover, contrast is established between the author's opinion and that of other researchers with the use of the conjunction while. In terms of information structure, the cleft allows the author to shift the main focus of the clause onto the feature that she considers essential. The explicit opposition between two points of view relates to polyphony. Indeed, the other linguists mentioned are given relative importance and indirectly participate in the argumentation of the article. However, the cleft places the author's viewpoint above that of the other linguists, which increases the persuasive dimension of the article. The focal attention of the cleft makes the author's point of view stand out compared to the opposite one. The fact that the author challenges the view of other researchers also illustrates the "tension between progress and continuity" described by Fløttum et al. (2006: 236) that is one of the distinctive features of research discourse. In [19], the authors are identifying the reason behind their choice of theoretical tools. The temporal subordinate clause in focus in the matrix clause corresponds to the condition that explains their point of view. The combination of the thematising structure and the discourse marker en effet reinforces the convincing aspect of the article. As Poncharal (2007) underlines, logical markers such as en effet appear more frequently in French in order to increase the textual coherence as well as the argumentative impact of the ideas developed. To a certain extent, the marker also helps the reader identify both the claim and the justification of the authors more easily. Similarly to [18], the clause is subjective. Stance-taking is notably revealed by the adjective pertinent [relevant] that denotes a judgement by the authors. It is nonetheless worth noting that French researchers tend to be more reserved regarding personal engagement. While the author is assertive in the English occurrence in [18], the authors in [19] qualify their judgement with the verb sembler [seem]. Although there are traces of authorial identity in both languages, English appears to allow more subjectivity in the argumentation than French. This finding is in line with the concept of "moi baïsable" already mentioned for the role of researcher. Because of the academic training and the rules imposed by French journals, the subjectivity of French researchers remains limited. The more significant use of logical markers in French can be interpreted as compensating for this constraint.

\subsubsection{Author as writer}

Finally, the author as a writer aims at clearly defining the outline of his or her work and guiding the reader throughout the article. Occurrences illustrating the role 
of writer show no significant difference between the two languages. It is the least frequent role in the French sub-corpus and the second least represented one in the English sub-corpus. Overall, it is a minor role. However, it still plays a relevant part in the argumentation as shown in [20] and [21]:

[20] Many of these data are taken from Newman, 1996. I can do justice neither to the detailed background nor to the comprehensive description of LVCs in GIVE that appear in this book. Newman makes relevant observations throughout; however, it is Section 5.6 which relates most directly to this discussion of LVCs.

(engling37)

[21] Par ailleurs, D.L. n'envisage pas une possible parenté avec la construction tout $+N$, et par là avec tous + les $N$. C'est ce point que je vais examiner ici.

(frling13)

\section{'[...] It is this point that I will examine here.'}

In Example [20], the author is pointing out which section of her article deals with $L V C$ s, an element introduced in the preceding sentence. The aim is to anticipate the potential interrogations of the readership by indicating that the issue in question will be tackled at a later point in the article. As for [21], the element in focus ce point refers to the fact presented in the preceding sentence. The discursive role of the cleft is to underline the aim of this subsection by giving a referential value to the highlighted constituent. This is justified by the fact that the occurrence is part of the opening lines of the subsection (see Section 4.5). In this case, the cleft also highlights that a new argumentative stage is being developed. In other words, the combination of the greater focus put on, the NP ce point, and the adverb of place ici denotes a change in the topic of discussion. As far as research discourse is concerned, these changes, whether explicit as in [21] or more implicit, usually reflect the research process the author has gone through when writing the article. The presentation of this logical process of questioning and explaining facilitates the reader's understanding. The analysis is thus in accordance with the findings of the previous sections.

I have shown in this section that the role assigned to the author in cleft constructions may differ in nature and may correspond to different subjective/ objective levels. While the author as presenter and quoter remains neutral, the author as writer, researcher and arguer displays a higher degree of subjectivity. As for the functional aspect, I have demonstrated that clefts can participate in the establishment of a framework as well as a structure for the article. They can also help the author guide the reader by inducing a particular meaning or increase the reader's understanding. Overall, what the results reveal is that the role of clefts in research discourse is not to introduce arguments but instead to participate in the establishment of discursive coherence and clarity. 


\subsection{Information structure}

Clefts modify the information structure by either shifting the primary focus onto what would typically be backgrounded information or by laying additional emphasis on elements already receiving the main focus. Linguists, however, do not agree on the nature of the information highlighted. The common assumption is that the matrix clause only highlights new or non-shared information while the relative that-clause contains given or shared information (see Declerck, 1984). In other words, clefts are seen as complements to the shared information. More recent studies such as Delin and Oberlander (1995), Lahousse and Borremans (2014), and Park (2003) question this claim and underline the possibility for clefts to highlight given or already shared information. This section is an attempt to settle this issue.

Table 6 below summarises the findings for French and English.

\begin{tabular}{|l|r|r|r|r|r|r|}
\hline & \multicolumn{3}{|c|}{ French } & \multicolumn{3}{c|}{ English } \\
\cline { 2 - 7 } & Economics & Linguistics & Subtotal & Economics & Linguistics & Subtotal \\
\hline Non-shared & $72.5 \%$ & $54 \%$ & $59 \%$ & $59 \%$ & $56 \%$ & $57 \%$ \\
\hline Shared & $27.5 \%$ & $46 \%$ & $41 \%$ & $41 \%$ & $44 \%$ & $43 \%$ \\
\hline Total & $100 \%$ & $100 \%$ & $100 \%$ & $100 \%$ & $100 \%$ & $100 \%$ \\
\hline
\end{tabular}

Table 6 - Nature of the information of the clefted element

Table 6 shows that the cleft constructions found in my corpus include shared and non-shared information and that French and English both follow the same pattern. In comparison to the different studies bearing on the nature of the information that receives focal attention in clefts, we can conclude that our results confirm the more recent claims that clefts can highlight both shared and non-shared information. As for disciplines, our results reveal different patterns in the two languages. However, this difference will not be investigated in this study. I will now turn to a qualitative analysis of several examples to see how the types of information are conveyed and see if any differences appear. I will first analyse Examples [22] and [23] highlighting non-shared information:

[22] Unlike the pitch accent categories, which are associated with whatever grammatical entity the accent falls within, the boundaries are autonomous string elements, much like the punctuation marks that on occasion represent them in the orthography. It is combination at the syntactic level that makes them coarticulate with the words. (engling16)

[23] Par contre, il est possible "d'appuyer sur telle ou telle clé de la clarinette" ou encore de dire que "la clé fonctionne", puisqu'on peut la considérer en soi comme "un mécanisme" NNN7, mais ces séquences paraitraient peu naturelles appliquées à une clé de porte. [...] 
7. Le Dictionnaire de la musique (1976: 1-221) précise que “c'est à Frederick Nolan (1808) et à Theobald Boehm (flûte traversière, 1832) que l'on doit les perfectionnements les plus efficaces dans le fonctionnement de ce nouveau mécanisme" (cnqs). (frling47)

"However, it is possible "to press this or this clarinet key" or say that the "clarinet works" since we can see it as a "mechanism" NNN7 [...]

7. The Music Dictionary explains that "it is to Frederick Nolan and Theobald Boehm that we owe the most effective improvements in the functioning of this new mechanism".'

In Examples [22] and [23], the elements in focus cannot be retrieved from the preceding clauses nor presupposed by the reader. In [22], the highlighted noun phrase combination at the syntactic level corresponds to the grammatical feature that explains the coarticulation between punctuation marks and words. While these two components are already referred to in the preceding clause - with words referring back to orthography and them to punctuation marks -, the theme is here introduced for the first time. Unlike the other pieces of information contained in the clause, combination at the syntactic level has no referential equivalent and the emphasis laid on it with the cleft further underlines its newness in the information structure as well as its newsworthiness. Moreover, the cleft introduces here a new fact, which reinforces the claim I made that the item cannot be seen as logically presupposed by the reader. Instead, the NP in focus is additional knowledge that is necessary for the reader to understand the issues at stake. As for [23], the goal of the cleft, which appears in the notes of the article, is to complete the clause bearing the note in the body. For reasons of clarity in the analysis, this clause is included with the note in the example. The items in focus à Frederick Nolan and $\grave{a}$ Theobald Boebm designate the two key figures in the history of flutes. Similarly to the element in focus in [22], they are mentioned for the first time in the matrix clause of the cleft and cannot be recovered from any of the constituents of the corresponding clause. Moreover, the cleft also modifies the thematic structure by shifting the clefted element from a rheme position to a theme position. Example [23] is thus more marked than [22]. The cleft does not only function as a reference but also as a fact. The discursive role of the cleft is to emphasise new information for the reader to quickly and precisely identify it. In this case, the items can be labelled as non-shared.

Although clefts containing non-shared or new information are more frequent in my corpus, the number of clefts highlighting already shared information remains substantial, which challenges Declerck's (1984) claim. Let us focus on Examples [24] and [25]:

[24] In one of these logical forms, his quantificational semantics for definite descriptions takes wide scope over the negation operator, thereby leaving the existential implication unnegated (P-preservation), and in the other, the description falls within the scope of negation (P-cancellation). It is the latter that occurs in example (1). (engling08) 
[25] D'abord, l'expression "langage intérieur" semble désigner avant tout pour la tradition philosophique une conception particulière non pas tant du langage que de la pensée. Dans cette tradition, c'est en effet de la pensée qu'il est dit qu'elle est un "langage intérieur", un "discours mental”, ou, pour reprendre la formulation platonicienne "un dialogue intérieur et silencieux de l'âme avec elle-même”.

(frling22)

"Firstly, the expression "internal language" seems to first and foremost designate for the philosophical tradition a particular conception not so much of language but of thinking. In this tradition, it is indeed of thinking that it is said that it is an “internal language" [...].'

Both examples present already shared items as the highlighted elements, that is to say, the constituents in focus, have either already been mentioned in the preceding clauses or are considered to be known by the reader. In the case of [24], the highlighted NP the latter refers to $P$-cancellation mentioned in the previous sentence. The NP functions here as a lexical anaphora. The noun latter is a way to avoid the direct repetition of the antecedent while marking a contrast between $P$-cancellation and P-preservation. This cleft does not serve to introduce a new element but to complete one that has already been introduced, and it is the relative clause that provides non-shared information. In that sense, it departs from the "prototypical contrastive clefts" mentioned by Declerck (1988). The discursive role of the cleft is thus to facilitate the reader's understanding of the text by avoiding any cognitive overload. This discourse function is in accordance with the results of Poncharal (2010) who argues that anaphora helps maintain coherence. This claim is also true for Example [25], in which the cleft introduces a repetition of the noun la pensée. However, in this case, both the anaphora and its antecedent are identical. The repetition is accompanied by the sentence adverb en effet whose role is to link the two propositions and introduce the specification provided by the author of the argument contained in the first proposition. Indeed, the cleft as a whole aims at supporting the author's claim. Similarly to [23], there is, in this case, a combination of theme and focus that places the indirect object at the forefront of the sentence. As a result, the discursive role of the cleft is here to increase the coherence as well as the persuasive dimension of the article. As mentioned earlier, adding discourse markers in French such as en effet not only structures the argumentation but also reinforces the different claims of the author. This need for a more explicit structuring is far less present in English (Poncharal, 2007). [25] exemplifies the more direct role clefts can play in the argumentation.

[24] and [25] have shown that lexical anaphoras, as examined by Poncharal (2010), are used both in French and in English to introduce shared information. They can also be used in combination with grammatical anaphoras ${ }^{4}$ as in [26] and [27]:

4. Halliday and Hasan (1976) and Kosseim et al. (1996) distinguish between two types of anaphora: lexical anaphora uses lexemes belonging to an open lexical class such as nouns, verbs, adjectives or 
[26] Both sectors produce homogenous goods: one is perfectly competitive with constant returns to scale technology; and the other is imperfectly competitive, with Cournot competition and free entry and exit, and increasing returns to scale technology both at the firm and plant level. It is this imperfectly competitive sector that is of interest for the purposes of our study.

(engecon42)

[27] Dans cet article nous utilisons des données sur les émissions de certificats de dépôts français pour étudier la sensibilité du taux à l'émission des certificats de dépôts au moment émis. Il s'agit de répondre à la question: une banque paie-t-elle plus cher une offre accrue de certificats de dépôts? C'est ce comportement du taux à l'émission des certificats de dépôts en fonction du montant émis qui permettra de juger de la plus ou moins grande élasticité du financement extérieur des banques. (frecon48)

'In this article, we use data on the issue of French deposit certificates to study the sensitivity of the rate of the issue of deposit certificates [...] It is this behaviour of the rate of the issue of deposit certificates [...].'

In Example [26], the NP in focus this imperfectly competitive sector is a repetition of the underlined adjective phrase from the preceding proposition. The anaphora is here both lexical as the antecedent is repeated and grammatical as it is introduced by the demonstrative determiner this. The use of a demonstrative induces an operation of pinpointing that links the two propositions and reinforces the lexical anaphora. By doing so, it reinforces the semantic continuity in the paragraph and is a way to make it simpler for the reader to process information. Furthermore, the cleft as a whole indicates the specific interest of the authors regarding their article as well as their motivation. The cleft thus increases the coherence in two definite ways. On the one hand, it provides the reader with the necessary background to understand the issues at stake in the article and on the other hand, the anaphoric nature of the cleft establishes a semantic consistency. Occurrence [27], taken from the abstract of a French economics article, also exemplifies the use of lexical anaphora reinforced by a grammatical anaphora. The continuity established through this combination is especially crucial for abstracts, whose goal is to efficiently and quickly convince the reader. The nature of the information contained in clefts can, therefore, be either shared or non-shared. This finding goes against the claim of linguists such as Declerck who argue that clefts only highlight non-shared information. Moreover, depending on the status of the information, clefts do not fulfil the same roles. While clefts containing non-shared information tend to help the reader identify the newsworthy knowledge, clefts containing shared information establish semantic continuity. I have also briefly mentioned that the place of clefts could influence their functional role. I will develop this point in the following subsection.

adverbs while grammatical anaphora uses lexemes belonging to a closed lexical class such as pronouns, demonstrative adjectives or indefinite articles. 


\subsection{Discursive position in the article}

The previous section showed that the place of clefts influences their discursive role both in French and in English articles. However, one issue still has to be tackled: from a French-English contrastive viewpoint, do clefts have different discursive positions within articles in the two languages? If so, do the differences observed illustrate the more reader-oriented nature of English research discourse posited by Celle (2013), Poncharal (2010), and Carter-Thomas (2014)? This finding is tested in the following section.

\begin{tabular}{|l|r|r|r|r|r|r|}
\hline & \multicolumn{3}{|c|}{ French } & \multicolumn{3}{c|}{ English } \\
\cline { 2 - 7 } & Economics & Linguistics & Subtotal & Economics & Linguistics & Subtotal \\
\hline Abstract & $3 \%$ & $3 \%$ & $3 \%$ & $6 \%$ & 0 & $2 \%$ \\
\hline Introduction & $20 \%$ & 0 & $6 \%$ & $16 \%$ & $3 \%$ & $7 \%$ \\
\hline Body & $75 \%$ & $88 \%$ & $84 \%$ & $56 \%$ & $81 \%$ & $73 \%$ \\
\hline Conclusion & 0 & 0 & 0 & $9 \%$ & $6 \%$ & $7 \%$ \\
\hline Notes & $2 \%$ & $9 \%$ & $7 \%$ & $13 \%$ & $10 \%$ & $11 \%$ \\
\hline Total & $100 \%$ & $100 \%$ & $100 \%$ & $100 \%$ & $100 \%$ & $100 \%$ \\
\hline
\end{tabular}

Table 7 - Place of clefts in articles

We can see in Table 7 that the majority of clefts are located within the body of articles. The quantitative analysis shows that in terms of language, clefts located in the body are more frequent in French than in English. Our claim concerning this difference is that clefts located in the other parts - abstract, introduction, conclusion or notes - are more prone to participate in the structuring of the article while those found in the body are more likely to be linked to the strengthening of semantic continuity. There are, for that matter, no clefts in the conclusion of French articles whereas they represent 7\% of the English sub-corpus. The differences regarding discursive position point to the reader-oriented nature of English articles. As for the discipline factor, clefts are more frequently found in the body of linguistics articles than in economics articles. This difference is offset by the greater proportion of clefts found in the introduction of economics articles. Based on these results, economists appear to favour exhaustive and guiding introductions in comparison to linguists. However, introductions to economics articles tend to be longer in comparison to the body and to the introductions in linguistics. This explains the higher proportion of clefts in economics introductions. Let us now turn to a qualitative analysis of two case studies to test our hypothesis on the nature of the reader-author relationship in the two languages. The first article under study is an English economics article (engecon23). This article is particularly relevant for our analysis as the five clefts it contains can be found in four of the five parts of the article and is representative of the English sub-corpus. The occurrences are listed below: 
- Abstract

[28] Our model demonstrates that in many cases it is the sector bias of SBTC that determines SBTC's effect on relative factor prices, not its factor bias.

- Introduction

[29] The key message is that in a multi-sector framework, in many cases it is the sector bias of TC, rather than the factor bias or any rate of change in factor bias, that determines TC's effect on relative wages.

- Section 2: Theoretical framework

[30] Thus, in a one-sector economy it is the factor bias of TC that affects relative factor prices.

[31] The central message of this section is that in a multi-sector framework, in many cases it is the sector bias of TC, rather than the factor bias or any rate of change in factor bias, that determines TC's effect on relative wages.

- Conclusion

[32] First, using a two-factor, two-sector, two-country model we demonstrated that in many cases it is the sector bias of SBTC that determines SBTC's effect on relative factor prices, not its factor bias.

All five clefts have an NP as their highlighted element. Examples [28] and [32] share the same NP and the same semantic meaning. The authors are presenting the main finding of their study regarding factor prices and sector bias. At the lexical level, the use of the research verb demonstrate and of the possessive determiner our indicates that the authors take on the role of researcher. Although the two clefts are built on an identical model, the difference between them lies in their position. [28] occurs in the abstract whereas [32] is part of the conclusion. Because of the opposite roles of the two parts, the discursive function of the clefts differs. The role of an abstract is to present the subject and the different claims of a research article while the role of the conclusion is to summarise the results. As a result, the former has a much more persuasive dimension than the latter. In the case of [28] and [32], the difference is expressed through verbal tenses. On the one hand, the present tense in [28] reflects the factual aspect of the assertion. The authors are purposefully and concisely explaining what their findings are to invite the reader to read their article. On the other hand, the preterite used in [32] indicates that the argumentation is completed and that the hypotheses have been confirmed. In other words, the first example serves to provide the reader with the outline while the second serves to reassert the conclusions of the study in order for the reader to remember the fundamental issues tackled. In the same way, occurrences [29] 
and [31] highlight the same element central/key message and illustrate the same authorial role of writer. The discursive role of the clefts is to lay emphasis on the authors' claim. Incidentally, this claim is introduced by the cleft in [30]. Indeed, the cleft located in the body of the article is used to shed light on the logical result the authors draw from their analysis. This is revealed by the adverb thus. [29] and [31] reiterate the same claim but do not introduce any new element. However, while [29] is located in the introductory section of the article, [31] is part of the subsection devoted to the summary of the theoretical discussion. Once again, the authors use the first cleft to present their main argument before developing it while they use the second to conclude their development. The repetition of the same sentence creates clear demarcations for the different sections of the article. It acts as a complement to subtitles. Moreover, the anaphoric nature of the clefts and the way the authors regularly punctuate the discourse with their claim increase the persuasive dimension of the article. The case study thus reveals the relationship between place of occurrence and argumentative role of clefts. As far as French is concerned, no equivalent where clefts belonging to different parts of an article made the structure as explicit was found in the corpus. This is explained by the fact that $84 \%$ of the clefts are part of the body of the articles.

I have shown here that the use of clefts can increase the persuasive aspect of research articles by repeating the author's main arguments. They can also act as a structuring device for the article by explicitly marking out the different sections and topical changes. This finding is valid for English and French. The difference between the two languages, therefore, lies in the distribution of clefts. In light of the findings of Section 4.3, the case study illustrates the tendency for English to mix different authorial roles and discursive positions of the clefts. It appears that English tends to distribute the thematising structures in the different discursive parts to guide the reader throughout the whole article. Moreover, the higher frequency of use of clefts in notes and conclusions denotes a more thorough guiding of the reader. Let us analyse two examples from the English sub-corpus to justify this claim:

[33] Our measure of investment costs is a comprehensive one, based on factors such as foreign investment controls, immigration laws, hiring and firing practices, anti-trust laws, state control of enterprises and the accessibility of local and foreign capital markets. NNN3

3. It is the same measure of investment costs that is used in the Carr et al. study which estimates an FDI equation, however it has not been included in a trade equation before.

(engecon42)

[34] Many dozens of localities are contained within this area. Looking at all of them would be a very time consuming task, hence we decided to focus on a "test case", an area of the country which could be looked at in detail, and which was fairly representative NNN13 of other parts of England. 
13. We do not mean here to suggest that the existence of the subjunctive, and the forms it takes, can be inferred for one local dialect on the basis of results relating to another. Rather, it is the implications for methodological issues which we expect to carry over to the study of the were-subjunctive in other areas of the country. (engling26)

Example [33] provides additional information about the measuring tool the author uses to analyse his data. In this case, the author is explaining the difference in the way he uses the measuring tool in question compared to the way other economists - Carr et al. - do. The link between the attached proposition and the note is made explicit by the anaphora. The element in focus is a repetition of the subject and theme measure of investment costs. The functional role of the cleft here is to anticipate the potential questions the readership may have by clearly indicating the point of departure from other studies and the motivation behind it. This anticipation is especially useful since the article is primarily targeted for members of the same scientific community who may have read the study mentioned. As far as [34] is concerned, the role of the note is to clarify the authors' claim regarding their choice of case study. The sentence attached to the note suggests that their test case is particularly relevant as it reflects the general pattern existing in England. However, the note highlights the fact that it is representative regarding methodology but not concerning results. The cleft allows the authors to lay extra emphasis on the actual interest of the authors while dismissing the potential inaccurate interpretation. The discursive motivation of the cleft is here to avoid misunderstanding and guide the readership's interpretation. The more significant use of notes in English research articles thus illustrates its more reader-oriented nature. By providing additional information, the author is both anticipating questions the readership may have and facilitating their understanding of the article.

I have shown in this subsection that the place of clefts plays a role in the argumentation. The combination of the repetition of arguments and the emphasis put on them with cleft constructions creates an explicit structure for the article that accompanies the titles and subtitles. To a greater extent, it guides the reader and influences his or her understanding. The difference between French and English is revealed in the distribution of clefts. Although most clefts occur within the body of the article in both French and English, the latter relies on clefts in notes more frequently to provide additional information to facilitate the grasping of the arguments.

\section{Conclusion}

In the present study, I have attempted to show that cleft constructions play a role in the argumentative dimension of English and French research articles. To do so, I carried out an analysis of a corpus made of 40 articles focusing mainly on the discursive features of clefts. 
First, the syntactic analysis revealed that the clefts used in research discourse do not differ from clefts outside academic discourse. I have found that the clefted elements are mainly NPs and correspond in most cases to the subject of the relative clause. The semantic analysis revealed that cleft constructions in research discourse can strengthen semantic continuity between the elements in focus, which contributes to the discursive coherence of an article.

Secondly, I have suggested that the discursive functions of clefts are related to authorial identity as well as their discursive position in the article. The five authorial roles that I have examined - writer, researcher, arguer, presenter and quoter - differ in nature and subjectivity. While the author as presenter and quoter does not rely on any individual commitment, the roles of writer, researcher and arguer denote his or her point of view. As for the functional aspect, I have shown that references allow the author to define a framework whereas the roles of writer and researcher participate in the establishment of a clear structure. The writer as arguer can guide the readership by inducing a specific meaning to convince them and the introduction of facts related to the subject increases the readers' understanding. Regarding the discursive position of clefts, my analysis showed that the combination of the repetition of arguments and the emphasis laid on them with cleft constructions creates an explicit structure that accompanies the article's titles and subtitles.

Thirdly, I have challenged Declerck's (1984) claim on the nature of the information contained in clefts. The results of the analysis of the information structure of clefts revealed that they can highlight either non-shared or shared information. In this sense, the results support previous analyses (Lahousse $\&$ Borremans, 2014; Delin \& Oberlander, 1995; Park, 2003). Moreover, depending on the status of the information clefts do not fulfil the same roles. While clefts containing non-shared information tend to help the reader identify the newsworthy knowledge, clefts containing shared information favour the reinforcement of semantic continuity.

Finally, the contrastive analysis of $i t$-clefts and c'est-clefts reveals several differences between French and English research discourse. The main difference between the two languages lies in the frequency of use of cleft constructions. Due to the stricter word order of French, clefts are more frequently used in French articles, which corroborates Carter-Thomas's (2009) findings. The second significant difference between French and English research articles is the author-reader relationship. While French tends to be more reader-responsible, English, on the other hand, is more reader-oriented. In other words, English researchers are more eager to guide the reader and facilitate his or her understanding of the article. This attitude is illustrated by the distribution of clefts as well as the role the author takes on. English relies more on the use of notes and the role of writer is more frequent than in French. These results are in line with the recent work on argumentative discourse by Hyland (1998), Poncharal $(2007,2010)$ and Celle (2013). It appears relevant to conduct further research to confirm the claims I have made. It would be particularly interesting to complete this study with the analysis of a translated corpus to test the differences between French and English clefts concerning discursive function. 


\section{References}

Bakntin, M. 1984. Problems of Dostoevsky's Poetics. Minneapolis: University of Minnesota Press.

Carter-Thomas, S. 2002. Theme and Information Structure in French and English: A Contrastive Study of Journalistic Clefts. In C.A.M. Gouveia, C. Lopes DA Costa, E. Ribeiro Pedro, L. Azuaga \& S. Barcelos (eds.), 14th Euro-International Systemic Functional Workshop - EISFW 2002 (University of Lisbon, Portugal - 24-27 July 2002).

Carter-Thomas, S. 2009. The French C'est-Cleft: Function and Frequency. In D. Banks, S. EASON \& J. ORMroD (eds.), La linguistique systémique fonctionnelle et la langue française. Paris: L'Harmattan: 127-157.

CARTER-Thomas, S. 2014. Valeurs et fonctions des éléments initiaux commentaires. Analyse contrastive d'un corpus d'articles de recherche en économie. Corpus 13: 99-128. Available online: http://journals.openedition.org/corpus/2455.

Carter-Thomas, S. \& Rowley-Jolivet, E. 2013. Rapporter la voix de l'autre dans les articles de recherche en anglais: problèmes et enjeux pour le chercheur francophone. In C. Desoutter \& C. Mellet (eds.), Le discours rapporté: approches linguistiques et perspectives didactiques. Bern - Berlin - Brussels: P. Lang: 163-184.

Celle, A. 2013. Interrogation, hypothèse, argumentation. Le français et l'anglais en contraste. In B. Lewandowska-Tomaszczyk \& M. Thelen (eds.), Translation and Meaning. Maastricht: University of Maastricht: 93-107.

Celle, A. \& Lansari, L. 2014. La prédication seconde détachée en position initiale en anglais et en français. Corpus 13: 129-163. Available online: http://journals.openedition. org/corpus/2466.

Collins, P.C. 1991. Cleft and Pseudo-Cleft Constructions in English. London: Routledge. Declerck, R. 1984. The Pragmatics of It-Clefts and Wh-Clefts. Lingua 64 (4): 251-289.

Declerck, R. 1988. Studies on Copular Sentences, Clefts, and Pseudo-Clefts. Leuven: Leuven University Press.

Declerck, R. 1994. The Taxonomy and Interpretation of Clefts and Pseudo-Clefts. Lingua 93 (2-3): 183-220.

Delin, J. \& Oberlander, J. 1995. Syntactic Constraints on Discourse Structure: The Case of It-Clefts. Linguistics - An Interdisciplinary Journal of the Language Sciences 33 (3): 465-500.

Dufter, A. 2009. Clefting and Discourse Organization: Comparing Germanic and Romance. In A. Dufter \& D. Jасов (eds.), Focus and Background in Romance Languages. Amsterdam - Philadelphia: J. Benjamins: 83-121.

Fløttum, K., Gedde-Dahl, T. \& KinN, T. 2006. Academic Voices: Across Languages and Disciplines. Amsterdam - Philadelphia: J. Benjamins.

Granger, S., Lerot, J. \& Petch-Tyson, S. 2003. Corpus-Based Approaches to Contrastive Linguistics and Translation Studies. Amsterdam - New York: Rodopi. Chapter I: The Corpus Approach - A Common Way Forward for Contrastive Linguistics and Translation Studies? 17-29.

Halliday, M.A.K. 1967. Notes on Transitivity and Theme in English: Part 2. Journal of Linguistics 3 (2): 199-244. 
Halliday, M.A.K. \& Hasan, R. 1976. Cohesion in English. London: Longman.

Hinds, J. 1987. Reader versus Writer Responsibility: A New Typology. In U. Connor \& R.B. Kaplan (eds.), Writing across Languages: Analysis of L2 Text. Reading: AddisonWesley: 141-152.

Hyland, K. 1998. Persuasion and Context: The Pragmatics of Academic Metadiscourse. Journal of Pragmatics 30 (4): 437-455.

Hyland, K. 2002a. Authority and Invisibility: Authorial Identity in Academic Writing. Journal of Pragmatics 34 (8): 1091-1112.

Hyland, K. 2002b. Directives: Argument and Engagement in Academic Writing. Applied Linguistics 23 (2): 215-239.

Katz, S. 2000. A Functional Approach to the Teaching of the French C'est-Cleft. The French Review 74 (2): 248-262.

Kosseim, L., Tutin, A., Kittredge, R. \& Lapalme, G. 1996. Generating Grammatical and Lexical Anaphora in Assembly Instructional Texts. In G. Adorni \& M. Zock (eds.), Trends in Natural Language Generation: An Artificial Intelligence Perspective. Berlin - New York: Springer: 260-276.

Lahousse, K. \& Borremans, M. 2014. The Distribution of Functional-Pragmatic Types of Clefts in Adverbial Clauses. Linguistics 52 (3): 793-836.

Lambrecht, K. 1994. Information Structure and Sentence Form: Topic, Focus, and the Mental Representations of Discourse Referents. Cambridge: Cambridge University Press.

LAmbrecht, K. 2001. A Framework for the Analysis of Cleft Constructions. Linguistics - An Interdisciplinary Journal of the Language Sciences 39 (3): 463-516.

Nølke, H., Fløttum, K. \& Norén, C. 2004. ScaPoLine: la théorie scandinave de la polyphonie linguistique. Paris: Kimé.

PARK, S.-Y. 2003. Information Structure of It-Clefts. Seoul National University Working Papers in English Language and Linguistics 2: 41-60.

Pic, E. \& Furmaniak, G. 2012. Les modes de discours, interface entre texte et grammaire dans les langues de spécialité. $A S p$ 62: 25-44. Available online: http://journals. openedition.org/asp/3091.

Poncharal, B. 2007. Cohérence discursive en français et en anglais: fonction des connecteurs dans la traduction. In A. Celle, S. Gresset \& R. Huart (eds.), Les connecteurs, jalons $d u$ discours. Bern: P. Lang: 117-136.

Poncharal, B. 2010. La traduction de l'anaphore dans la prose de pensée. Palimpsestes 23: 41-62. Available online: http://journals.openedition.org/palimpsestes/454.

PRINCE, E.F. 1978. A Comparison of Wh-Clefts and It-Clefts in Discourse. Language 54 (4): 883-906. 